\title{
INOVASI PENDIDIKAN AGAMA DI SMP FRATER BINAAN YAYASAN TAMAN TUNAS KOTA KENDARI
}

\section{THE INNOVATION OF RELIGIOUS EDUCATION IN FRATER OF JUNIOR HIGH SCHOOL, KENDARI CITY}

\author{
Amiruddin \\ Balai Penelitian dan Pengembangan Agama Makassar \\ Jl. A.P. Pettarani No. 72 Makassar \\ Email: amiruddinalbarru@yahoo.co.id
}

Naskah diterima tanggal 4 Oktober 2017. Naskah direvisi 13 Oktober 2017. Naskah disetujui 30 Oktober 2017.

\begin{abstract}
Abstrak
Penelitian ini bertujuan untuk mendeskripsikan proses implementasi dan inovasi pembelajaran pendidikan agama di SMP Frater Kendari yang merupakan sekolah Katholik, binaan Yayasan Taman Tunas yang memiliki latarbelakang peserta didik yang multi agama. Rumusan Masalah yang ada dalam penelitian ini adalah: Bagaimana Inovasi Pendidikan Agama yang diimplementasikan serta faktor pendukung dan penghambat dalam proses Inovasi Pendidikan Agama di SMP Frater Kendari?Penelitian ini menggunakan pendekatan kualitatif dengan teknik pengumpulan data berupa wawancara, observasi, dan studi dokumentasi. Hasil penelitian menunjukkan bahwa implementasidan inovasi pembelajaran pendidikan agama yang diterapkan adalah pembelajaran pendidikan agama Katholik untuk semua siswa tanpa melihat dari latar belakang siswa yang multi agama sesuai dengan ciri khas sekolah Katholik. Adapun materi pendidikan agama Katholik bersifat umum (universal) yang pembahasannya sedapat mungkin bisa dipahami oleh siswa yang beragama non Katholik.
\end{abstract}

Kata kunci: inovasi, pendidikan agama, yayasan keagamaan, Kendari

\begin{abstract}
This research aims to describe the implementation and innovation process of religious educational learning at The Junior High School of Kendari City SMP Frater Kendari which is a Catholic school, under management of Taman Tunas Foundation which has a multi-religious background of learners. Research Problem that exist in this research is: How the Innovation of Religious Education is implemented, as well as supporting and inhibiting factors in the process of Innovation of Religious Education. This study used a qualitative approach with data collection techniques in the form of interviews, observations, and documents studies. The results showed that implementation and innovation of learning of religious education applied is learning Catholic education for all students regardless of the multi-religious background of students according to the typical Catholic school. The material of Catholic religious education is general (universal) that the discussion as far as possible can be understood by non-Catholic students.
\end{abstract}

Keywords: innovation, religious educational, religious foundation, Kendari

\section{PENDAHULUAN}

$\mathrm{P}$ endidikan Nasional sebagai salah satu sektor pembangunan nasional dalam upaya mencerdaskan kehidupan bangsa, mempunyai visi dan misi terwujudnya sistem pendidikan sebagai pranata sosial yang kuat dan berwibawa untuk memberdayakan semua warga negara Indonesia berkembang menjadi manusia yang berkualitas sehingga mampu dan proaktif menjawab tantangan zaman yang selalu berubah.
Oleh karena itu, didalam undangundang sistem pendidikan nasional disebutkan bahwa; "Pendidikan nasional berfungsi untuk mengembangkan kemampuan dan membentuk watak serta peradaban bangsa yang bermartabat dalam rangka mencerdaskan kehidupan bangsa, bertujuan untuk berkembangnya potensi peserta didik agar menjadi manusia yang beriman dan bertakwa kepada Tuhan Yang Maha Esa, berakhlak mulia, sehat, berilmu, cakap, kreatif, mandiri, dan menjadi warga negara yang demokratis 
serta bertanggung jawab."(Direktorat Jenderal Pendidikan Islam DEPAG RI. 2006: 8).

Agama memiliki peran yang amat penting dalam kehidupan umat manusia. Agama menjadi pemandu dalam upaya untuk mewujudkan suatu kehidupan yang bermakna, damai dan bermartabat. Menyadari peran agama amat penting bagi kehidupan umat manusia maka internalisasi agama dalam kehidupan setiap pribadi menjadi sebuah keniscayaan, yang ditempuh melalui pendidikan baik pendidikan di lingkungan keluarga, di lembaga pendidikan formal maupun nonformal serta masyarakat.

Internalisasi nilai-nilai agama merupakan hal yang tidak boleh dilupakan dalam setiap elemen pendidikan. Semua peserta didik selain perlu memperoleh kesempatan mengembangkan intelektual, emosi, sosial, dan kinestetik tapi juga harus mengembangkan kecerdasan spritualnya. Lingkungan sekolah dapat memberikan penekanan terhadap aspek-aspek agama yang diajarkan kepada peserta didik(Husain, 2013: 2)Sebagaimana yang di usulkan Neil Postman, bahwa untuk mengawali pengenalan agama di sekolah dan memberikan kesempatan untuk mempelajari pendidikan agama (Neil Postman, 2001: 250).

Berbicara tentang Pendidikan Agama Kristen (PAK) pada dasarnya mengacu kepada sikap setiap agama yang ingin menjadikan ajarannya sebagai praktis dalam kehidupan manusia. Kita membayangkan, bahwa ajaran agama sebagai sebuah teori, sedangkan pendidikan agama sebagai prakteknya. Hal itu jelas jika kita kaitkan dengan apa yang sering dikatan orang, bahwa ajaran semua agama pada dasarnya baik, tinggal manusia yang menjalankannya. Sekiranya ada orang yang menganut agama tertentu, namun perbuatan dan jalan hidupnya tidak baik, jangan salahkan ajaran agamanya, melainkan salahkanlah penganut yang bersangkutan (Em. Budhiadi Henoch, 2006: 5).

Dalam RPJP yang diundangkan melalui Undang-Undang Nomor 17 Tahun 2007 kedudukan pembangunan fungsi pendidikan dan fungsi agama tidak terpisahkan dalam rangka pembangunan nasional dibawah payung pembangunan sumber daya manusia dan kesejahteraan rakyat. Perencanaan strategik pembangunan pendidikan agama dan keagamaan sebelum tahun 2010 telah berupaya meletakkan dasar bagi arah pembangunan yang mengintegrasikan kedua fungsi tersebut. Perumusan rencana strategik pendidikan agama dan keagamaan 2010-2014 diarahkan untuk melanjutkan pendekatan integratiftersebut sehingga memberikan kontribusi dan arti penting pendidikan agama dan keagamaan bagi pembangunan nasional secara keseluruhan.

Pendidikan agama diselenggarakan untuk memenuhi, a) tugas negara, pemerintah, masyarakat, keluarga, orang tua, wali dan lembaga sosial dalam melindungi hak-hak anak untuk menganut ajaran agamanya meliputi pembinaan, pembangunan dan pengamalan ajaran agama, b) memberikan layanan pendidikan untuk meningkatkan keimanan dan ketakwaan serta akhlak mulia dalam rangka mencerdaskan kehidupan bangsa dan hal ini sejalan dengan amanah Undang-Undang Dasar (UUD) 1945 tentang perlindungan anak.

Profesi guru merupakan pekerjaan yang mulia, sebab dari gurulah segala peradaban dimulai dan mengalami perkembangan yang sangat mengagumkan hingga detik ini. Namun, seiring dengan perkembangan zaman menuntut adanya peningkatan profesionalisme guru, maka profesi guru tentu harus direkonstruksi agar tidak seperti yang sekarang initerjadi. Pendidik di sekolah mempunyai peranan yang sangat penting dalam menentukan keberhasilan pembelajaran, dan guru jugasangat berperan dalam membantu perkembangan peserta didik untuk mewujudkan tujuan hidupnya secara optimal. Setiap guru di sekolah dituntut untuk mampu mendidik dengan baik dan menciptakan suasana yang kondusif bagi para pesertadidik untuk belajar.

Mendidik tidak hanya sekedar mentransfer ilmu kepada peserta didik, tetapi juga membuka pola pikir mereka bahwailmu yang mereka pelajari memiliki kebermaknaan untuk hidup mereka sehingga dari ilmu tersebut, mampu merubah sikap, pengetahuan, dan keterampilan merekamenjadi lebih baik. Penguasaan terhadap materi yang dikelola dan ditampilkan secara profesional, dari hati dan tanpa paksaan, logis, dan menyenangkan, serta dipadukan dengan pendekatan personalemosional terhadap peserta didik akan menjadikan proses pembelajaran yang ingin dicapai terwujud. Selain itu, pembelajaran juga harus dibuat bervariasi dengan menciptakan suatu metode pembelajaran yang baru atau dengan kata lain inovasi(Sadikin, 2013: 1-3).

Berbicara tentang inovasi, sebenarnya kata ini sering kali dikaitkan dengan perubahan, tetapi tidak setiap perubahan dikatakan sebagai inovasi. Inovasi adalah suatu ide, penemuan atau metode yang dirasakan atau diamati sebagai suatu hal yang 
benar-benar baru bagi seseorang yang bersifat relatif. Sedangkan inovasi pembelajaran yang dimaksud disiniadalah metode atau kiat seorang guru dalam membelajarkan siswa dengan berbagai tujuan tertentu. Inovasi pembelajaran merupakan sesuatu yang pentingdan harus dimiliki atau dilakukan oleh guru. Hal ini disebabkan karenapembelajaran akan lebih hidup dan bermakna. Kemauan guru untuk mencoba menemukan, menggali dan mencari berbagai terobosan, pendekatan, metode dan strategi pembelajaran merupakan salah satu penunjang akan munculnya berbagai inovasiinovasi baru

Penelititian ini di latarbelakangi oleh beberapa hasil penelitian sebelumnya untuk di kaji dan dikembangkan lebih lanjut. Diantaranya penelitian tentang Model Pembelajaran Pendidikan Agama pada Satuan Pendidikan Binaan Umat Kristiani di 4 provinsi (Sulawesi-Selatan, Sulawesi Utara, Maluku, dan Papua Barat) yang dilakukan oleh Balai Litbang Agama Makassar pada tahun 2009. Penelitian Survey Penyelenggaraan Pendidikan Keagamaan Kristen, Katholik, Hindu, Budha, dan Konghuchudi 33 provinsi yang dilakukan oleh Pusat Pendidikan Keagamaan Badan Litbang dan Diklat Kementerian Agama RI.

Penelitian serupa juga didasarkan pada hasil penelitian yang telah dilakukan oleh Balai Litbang Agama Semarang pada tahun 2010 yang dilaksanakan di Kalimantan Tengah, Bali, dan Nusa Tenggara Timur. Hasil penelitian tersebut merekomendasikan bahwa dalam pengembangan kurikulum pendidikan agama pada SMA-SMA swasta di bawah yayasan keagamaan jika memang sudah membuka diri menerima peserta dari pemeluk agama yang berbeda, maka dalam penyusunan kurikulum mengakomodir kepentingan peserta didik yang berbeda agama.

Penelitian terkait juga pernah dilakukan oelh Listia, Laode Arham dan Lian Gogali, 2007 tentang penelitian Problematika Pendidikan Agama di Sekolah-Sekolah SD, SMP, SMA di Kota Jogjakarta 2004-2006 dari hasil penelitian tersebut memberikan gambaran tentang pendidikan agama yang dilaksanakan oleh yayasan keagamaan diantaranya perlu diadakan pembaharuan sistem pendidikan agama, khususnya dalam segi materi pembelajaran, metode belajar, dan pemberdayaan guru agar lebih mampu menjadi pendidik yang kreatif dan inovatif memfasilitasi perkembangan kemampuan peserta didik dalam mengekspresikan iman dan kepercayaan untuk menjawab tantangan hidup para peserta didik.
Keempat hasil penelitian diatas menunjukkan bahwa masih ada satuan pendidikan yang dikelola yayasan keagamaan belum melaksanakan sebagian dari regulasi yang telah ditetapkan oleh pemerintah yaitu PP Nomor 55 tahun 2007 tentang Pendidikan Agama dan Keagamaan Khusunya pada pasal 4 ayat (2), bahwa setiap peserta didik pada satuan pendidikan semua jalur, jenjang dan jenis pendidikan agar memperoleh pendidikan sesuai dengan agama yang dianut dan diajar oleh pendidik yang seagama.

Berdasarkan pada paparan diatas, maka masalah pokok dalam penelitian ini adalah pendidikan agama pada satuan pendidikan binaan yayasan keagamaan di Kawasan timur Indonesia, dari masalah pokok ini maka di ajukan beberapa pertanyaan penelitian, yaitu: Bagaimana Inovasi Pendidikan Agama yang di Kembangkan oleh SMP Frater Kendari? dan apa Faktor Pendukung dan Faktor Penghambat dalam Mengembangkan Inovasi Pendidikan Agama di SMP Frater Kendari?

\section{Tinjauan Pustaka \\ Inovasi dalam Pembelajaran}

Perkembangan teknologi dan informasi yang cepat dalam berbagai aspek kehidupan termasuk dalam bidang pendidikan, merupakan suatu upaya untuk menjembatani masa sekarang dan masa yang akan datang dengan jalan memperkenalkan pembaharuan-pembaharuan yang lebih mengarah kepada efisiensi dan efektifitas. Kebutuhan akan layanan individual terhadap peserta didik dan perbaikan kesempatan belajar bagi mereka, telah menjadi pendorong utama timbulnya pembaharuan pendidikan. Oleh karena itu, lembaga pendidikan harus mampu mengantisipasi perkembangan tersebut dengan terus menerus mengupayakan suatu program yang sesuai dengan perkembangan anak, perkembangan zaman, situasi, kondisi, dan kebutuhanpeserta didik.

\section{Pengertian Inovasi}

Kata "innovation" (bahasa Inggris) sering diterjemahkan segala hal yang baru atau pembaharuan, tetapi ada yang menjadikan kata innovation menjadi kata Indonesia yaitu "inovasi". Terkadang istilah inovasi juga dipakai untuk menyatakan penemuan, karenahalyangbaruitu hasil penemuan. Kata penemuan juga sering dikaitkan dengan istilah "discovery" dan "invention". Diskoveri (discovery) adalah penemuan sesuatu yang sebenarnya benda atau hal yang ditemukan itu sudah ada, tetapi belum diketahui oleh khalayak luas. 
Misalnya penemuan benua Amerika. Sebenarnya benua Amerika itu sudah ada sejak lama, tetapi baru ditemukan oleh Columbus pada tahun 1492, maka dikatakan Columbus menemukan benua Amerika, artinya Columbus adalah orang yang pertama kali menjumpai benua Amerika.Sedangkan Invensi (invention) adalah penemuan sesuatu yang benarbenar baru, artinya hasil kreasi manusia. Benda atau hal yang ditemukannya itu sebelumnya benarbenar belum ada.Inovasi (innovation) ialah suatu ide, barang, kejadian, metode yang dirasakan atau diamati sebagai suatu hal yang baru bagi seseorang atau sekelompok orang (masyarakat), baik itu berupa hasil invention maupun diskoveri. Inovasi diadakan untuk mencapai tujuan tertentu atau untuk memecahkan suatu masalah tertentu(Udin Saefudin, 2008: 2-3).

Telah diketaui bahwa dibidang pendidikan banyak upaya telah dilakukan yang sifatnya pembaharuan dikenal dengan inovasi pendidikan. Inovasi menurut Rosabeth Moss Kanter (1986), adalah sebuah hasil karya pemikiran baru yang diterapkan dalam kehidupan manusia. Sedangkan menurut Amabile \& Conti (1999), inovasi adalah implementasi dan pemikiran baru oleh individu ataupun organisasi(Ancho, 2012: 34).

Secara umum inovasi memberikan gambaran bahwa jenis inovasi diantaranya: (1) inovasi proses; (2) inovasi metode (3) inovasi struktur organisasi: (4) inovasi dalam hubungan; (5) inovasi strategi; (6) inovasi pola pikir (mindset); (7) inovasi produk; (8) inovasi pelayanan. Kedelapan jenis tersebut berjalan secara integratif dan saling terkait. Sedeangkan inovasi pada prinsipnya dapat terjadi pada berbagai aspek, misalnya inovasi strategi pembelajaran, inovasi pola pikir pendidik dan tenaga kependidikan, inovasi model pembelajaran, dan inovasi pelayanan pendidikan. Semua jenisjenis inovasi tersebut pada ujungnya akan bermuara pada keunggulan sebuah sekolah terutama dalam memberikan jasa pendidikan (Ancho, 2012: 40).

\section{METODE PENELITIAN}

Penelitian ini dilakukan di Kota Kendari yang merupakan ibukota Provinsi Sulawesi Tenggara dengan mengambil lokasi penelitian pada SMP Frater Kendari yang merupakan salah satu sekolah di bawah binaan yayasan Katholik yaitu Yayasan Taman Tunas. Pelaksanaan penelitian selama 22 hari dengan dua tahapan yaitu tahapan penjajakan dilakukan selama 7 hari, dan tahapan pengumpulan data di lakukan selama 15 hari.
Sasaran penelitian dilakukan pada satuan pendidikan yang dikelola oleh yayasan keagamaan. Berdasarkan pada hasil penjajakan dengan kelayakan penelitian ditentukan sasaran penelitian pada SMP Frater Kendari yang di kelola oleh Yayasan Taman Tunas yang merupakan yayasan keagamaan Katholik.

Jenis penelitian merupakan penelitian kualitatif, dimana peneliti menjadi bagian dari key instrument (Bogdan, et.al (1982: 27).Peneliti ini mencoba memperoleh gambaran jelas tentang keterlaksanaan inovasi pembelajaran pendidikan agama di SMP Frater Kendari, kualifikasi dan kompetensi guru agama tersebut.Selain itu gambaran lain yang ingin diketahui adalah mengenai faktor pendukung dan penghambat dalam penerapan inovasi pembelajaran pendidikan agama.

Jenis dan sumber data yang diperoleh adalah data primer dan sekunder. Data primer berkaitan dengan informasi tentang inovasi pembelajaran pendidikan agama pada satuan pendidikan binaan yayasan keagamaan. Data tersebut akan diperoleh dari guru-guru mata pelajaran pendidikan agama yang mengajar di SMP Frater Kendari itu sendiri. Selain itu data tentang profil madrasah pun akan di peroleh dari administrator madrasah. Sedangkan data sekunder adalah yang berkaitan dengan informasi tentang bentuk inovasi yang dikembangkan oleh pendidik mata pelajaran agama, data base yang berkaitan dengan kependidikan, sosial, ekonomi, budaya dan keagamaan. Data tersebut akan diperoleh dari intansi-instansi pendataan, seperti Kantor Pemerintah Daerah, baik provinsi maupun kota/kabupten setempat, BPS setempat, Kantor Kanwil/Kementerian Agama setempat dan instansi-instansi lain yang menyediakan data base yang berkaitan dengan tujuan penelitian.

Informan ditentukan secara purposif, artinya informan ditentukan dengan pertimbangan mampu memberikan informasi yang berkaitan dengan permasalahan dan tujuan penelitian. Adapun informan yang dipilih berdasarkan pertimbangan peneliti adalah: 1) Kepala sekolah merupakan penanggungjawab dalam satuan pendidikan; 2) Wakil kepala sekolah bidang kurikulum, memiliki pengetahuan yang luas tentang kegiatan pembelajaran; 3) Pendidik yang mengampuh mata pelajaran pendidikan agama selaku pelaku utama dalam kegiatan pembelajaran.

Teknik pengumpulan data dalam penelitian ini menggunakan teknik sebagai berikut: 
teknik wawancara (interview) digunakan untuk memperoleh data mendalam mengenai inovasi pembelajaran pendidikan agama yang dilakukan oleh pendidik yang mengampuh mata pelajaran pendidikan agama di SMP Frater Kendari. Teknik ini digunakan mulai dari interviewpartisipasi, identifikasi serta persuasi dengan informan untuk menggali faktor pendukung serta faktor penghambat selama proses belajar mengajar pendidikan agama. Teknik observasi (pengamatan), teknik ini digunakan untuk mengetahui bagaimana pembelajaran agama kristen yang dilaksanakan oleh guru di kelas dan diamati mulai dari membuka materi, pembelajaran inti hingga menutup pelajaran agama. Selain itu mengumpulkan data dan gambaran umum yang meliputi letak geografis, sarana dan prasarana, keadaan guru dan siswa. Teknik Dokumentasi, Metode dokumentasi yang digunakan untuk memperoleh dokumendokumen penting yang terkait dengan pelaksanaan pendidikan agama SMP Frater Kendari. Dokumendokumen tersebut meliputi profil sekolah, tujuan pendirian sekolah, visi sekolah, kurikulum serta muatan kurikulum pendidikan agama. Khusus untuk pendidik yang mengampuh mata pelajaran pendidikan agama maka dokumentasi yang berkaitan komponen pendidikan akan ditelusuri secara mendalam.

Sebelum melakukan analisis data, maka peneliti melakukan pemerikasaan keabsahan data yang telah diterima sebagaimana yang dikemukakan Denzim dalam Quinn patton mengenai Triangulasi yang mengelompokkan empat tipe besar yakni triangulasi data adalah penggunaan beragam sumber data dalam suatu kajian; triangulasi investigator, yakni penggunaan beberapa evaluator atau ilmuan sosial yang berbeda; triangulasi teori, yakni penggunaan sudut panda ganda dalam menafsirkan seperangkat tunggal data; dan triangulasi metodologis yaitu penggunaan metode ganda untuk mengkaji masalah atau program tunggal (Quin Patton, 2009).

Adapun langkah-langkah yang digunakan dalam analisis ini adalah reduksi data, penyajian data dan verifikasi data (Sugiono, 2005: 92).Aktivitas dalam analisa data, yaitu data reduction, data display, conclusion drawing/verification (Sugiono,
2005). Analisa data selama di lapangan peneliti menggunakan model Spadley (Sugiono, 2005: 346) dalam penelitian kualitatif maka proses penelitian berangkat dari yang luas, kemudian memfokus dan meluas lagi. Terdapat tahapan analisa data yang dilakukan dalam penelitian kualitatif, yaitu analisa domain, taksonomi dan komponensial, analisa tema kultural.

\section{PEMBAHASAN \\ Profil SMP Frater Kendari}

Cikal bakal SMP Frater Kendari diinisiasi oleh para penggagas yang ikut prihatin terhadap perkembangan pendidikan di Kota Kendari di kala itu, bahwa dulu keberadaan sekolah belum terlalu banyak sehingga para penggagas berupaya mendorong pemerintah untuk bersama-sama ikut berpartisifasi meningkatkan pendidikan dan mencerdaskan bangsa. Sehingga pada tahun 1970 berdirilah sekolah ini yang diprakarsai oleh Yayasan Taman Tunas yang merupakan salah satu yayasan Katholik yang bergerak dibidang pendidikan dimana pengelolaannya di koordinir oleh para Frater. Yayasan Taman Tunas ini berkantor pusat di Makassar tepatnya di Jalan Kumala No. 151.

SMP Frater Kendari beralamat di jalan Sultan Hasanudin No. 73, berada di kota lama tepatnya di Kecamatan Kendari Barat, tepat dipinggir jalan raya dengan jarak ke pusat kota kecamatan $\pm 4 \mathrm{~km}$, dan jarak ke pusat kota kendari $\pm 7 \mathrm{~km}$ dengan menggunakan kendaraan umum seperti angkot, taksi, atau ojek. Lokasinya sangat strategis karena berada di pusat kota tepatnya di jalan Sultan Hasanuddin No. 73, Kecamatan Kendari barat, kelurahan Tipulu. Jarak sekolah ke ibukota kecamatan $\pm 4 \mathrm{~km}$, sedangkan jarak tempuh sekolah ke ibu kota $\pm 7 \mathrm{~km}$ yang dapat di akses dengan kendaraan umum yang setiap saat dapat di jumpai di sisi jalan.

Saat ini, SMP Frater Kendari di nakhodai oleh bapak Fr. Kornelis W Banin HHK, S.Pd., MM. Beliau juga pada periode tahun 2005-2009 pernah mencatatkan diri sebagai kepala sekolah yang ke 9 setelah itu di mutasi ke Makassar untuk menakhodai SMP Frater Makassar. Di usianya yang ke 44 tahun (kurung waktu 1970-2014), SMP Frater Kendari telah di pimpin sebanyak 11 orang kepala sekolah seperti yang terlampir pada tabel di bawah ini: 
Tabel. 1. Para Kepala Sekolah yang pernah menjabat di SMA Frater

\begin{tabular}{lll}
\hline No & Nama Kepala Sekolah & Tahun Ajaran \\
\hline 1 & Fr. Gregorius Duma HHK & $1970-1972$ \\
2 & Fr. Maximilianus HHK & $1994-1976$ \\
3 & Fr. Willy Sanapang HHK & $1976-1978$ \\
4 & Fr. Yulius Bambu Palamba & $1978-1981$ \\
& HHK & \\
5 & Nicolaus Sesa, BA & $1981-1994$ \\
6 & Erasmus Pongkahali & $1994-2000$ \\
7 & Fr. Apolinarus Ta'a HHK & $2000-2002$ \\
8 & Fr. Bonivasius Naru, HHK & $2002-2005$ \\
9 & Fr. Kornelis W Banin HHK, & $2005-2008$ \\
& S.Pd., MM & $2008-2011$ \\
10 & Fr. Felix Ledja, HHK & $2011-$ sekarang \\
\hline
\end{tabular}

SMP Frater Kendari memiliki tenaga pendidik sebanyak 23 orang, yang terdiri dari PNS 7 orang, Guru Tetap Yayasan (GTY) 9 orang, dan Guru Tidak Tetap (GTT) 7 orang. Sedangkan tenaga kependidikan sebanyak 5 orang yang terdiri dari Pegawai Tetap 3 orang dan Pegawai Tidak Tetap 2 orang. Jumlah pendidik dan tenaga kependidikan yang beragama Islam sebanyak 2 orang, Kristen 3 orang, Hindu 1 orang dan selebihnya beragama Katholik.

Kondisi peserta didik di SMP Frater untuk lima tahun terakhir mengalami perkembangan dari tahun ke tahun. Peserta didik yang tercatat untuk tahun ajaran 2013-2014 di SMP Frater ini sebanyak 301 peserta didik, dengan jumlah rombel sebanyak 9 yang terdiri dari 3 rombel untuk setiap tingkatan/ kelas.

Identifikasi peserta didik berdasarkan agama di dominasi oleh peserta didik yang beragama Katholik yaitu sebanyak 150 peserta didik, yang tersebar pada 3 tingkatan kelas. (kelas VII $=46$, kelas VIII $=58$, kelas IX $=46$ ). Peserta didik yang beragama Kristen sebanyak 119 dengan rincian $($ kelas VII $=52$, kelas VIII $=36$, kelas IX $=31)$, peserta didik yang beragama Buddha sebanyak 17 orang, terdiri dari (kelas VII $=4$, kelas VIII $=$ 7 , kelas IX $=6$ ), dan peserta didik yang beragama Islam sebanyak 15 , yang meliputi (kelas VII $=6$, kelas VIII $=4$, kelas IX $=5$ ).

\section{Inovasi Pembelajaran Pendidikan Agama di SMP Frater Kendari}

Kepala sekolah dalam satuan pendidikan adalah seorang pemimpin yang dapat menginspirasi seluruh warga sekolah yang didalam terdapat guru (pendidik), dan pegawai administrasi. Apalagi sebagai kepala sekolah di lembaga pendidikan swasta yang dikelolah oleh yayasan keagamaan sudah barang tentu tugas yang diembannya lebih terfokus untuk menjamin keberlangsungan organisasi sekolah sesuai dengan arah dan citacita yang di kehendaki oleh yayasan keagamaan tersebut.

SMP Frater Kendari adalah sebuah sekolah swasta yang di bina oleh Yayasan Taman Tunas yang merupakan salah satu yayasan keagamaan Katholik yang berkecimpung di dunia pendidikan yang pengelolaannya di percayakan oleh para Frater. Disamping yayasan taman tunas masih ada lagi yayasan Katholik yang konsen di bidang pendidikan seperti yayasan Yosef yang di kelolah oleh para Suster, dan yayasan Paulus yang pengelolaannya di tangani langsung oleh keuskupan (pastoral).

Pembelajaran pendidikan agama di SMP Frater Kendari hanya mengajarkan Pendidikan Agama Katholik yang diterapkan di semua kelas tanpa melihat dari latar belakang agama yang dianut oleh siswa dengan berpedoman pada kurikulum pendidikan agama Katholik. Sebenarnya pada beberapa tahun yang lalu kurang lebih lima tahun terakhir pernah menyediakan pendidik sesuai dengan agama yang dianut oleh siswa, namun saat sekarang ini tidak ada lagi pembelajaran pendidikan agama selain pendidikan agama Katholik. Hal ini di lakukan karena Konfrensi Wali Gereja Indonesia (KWI) melalui Majelis Pendidikan Katholik (MPK), yang menghendaki pembelajaran agama sesuai dengan ciri khas sekolah agama Katholik. Misi pendidikan Katholik harus sejalan dengan arah dan tujuan sekolah yang tertuang dalam kurikulum dan semua pendidik harus mengejawatahkannya dalam kegiatan pembelajaran.

Kegiatan pembelajaran pendidikan agama Katholik di SMP Frater Kendari sesuai dengan kebijakan Yayasan Taman Tunas yang dijabarkan kepala sekolah (pimpinan) dengan ketentuan seperti yang terlampir pada formulir pendaftaran siswa baru dengan cacatan yang bertuliskan bahwa: "SMP Frater Kendari hanya akan mengajarkan pengetahuan agama Katholik kepada semua siswa sesuai ciri khas sekolah Katholik". Sehingga sebelum siswa yang beragama selain mendaftar 
disekolah ini terlebih dahulu di berikan penjelasan dan pemahaman kepada orang tua atau wali siswa terhadap kebijakan sekolah tersebut.

Yayasan Taman Tunas setiap saat mengontrol perkembangan sekolah-sekolah yang dibinanya termasuk di SMP Frater Kendari dengan menempatkan salah seorang pengurus sebagai perwakilan yayasan. Lewat perwakilan yayasan inilah yang nantinya melaporkan perkembangan pendidikan di sekolah binaannya. Kepala sekolah sebagai pimpinan yang dipercayakan oleh yayasan senantiasa dituntut untuk meningkatkan kapasitas satuan pendidikan yang di pimpinnya baik dalam bentuk sarana dan prasarana pembelajaran, kemampuan supervisi dan manajerialnya, serta penyediaan tenaga pendidik berkualitas sesuai dengan kompetensinya.

Menurut kepala sekolah bapak Fr. Kornelis bahwa khusus untuk pendidik sangat dituntut agar setiap saat melakukan pembinaan kepada peserta didik. Ada tuntutan yang diemban, mereka harus mengolah, mempersiapkan pembelajaran lalu didalam proses pembelajaran menggali sebanyak mungkin potensi-potensi siswa yang dikaitkan dengan standar kompetensi yang harus dicapai. Diharapkan dalam proses pembelajaran siswa cukup berbaur antara siswa berbeda agama, sehingga tampak tidak ada kendala dalam menerima pelajaran agama khususnya pendidikan agama Katholik. Pendidik memang diharapkan kreatif, inovatif, memanfaatkan media pembelajaran, metode mengajar. apalagi di kurikulum 2013 modelnya seperti itu harus anak diberdayakan (Wawancara, Senin, 24/3/2014)

Selain itu, konsep dasar yang di tanamkan bahwa siswa yang diharapkan memiliki karakter peserta didik yang "pintar dan baik" artinya bahwa pintar itu tidak harus rangking atau menjadi yang terbaik tapi bagaimana peserta didik memahami materi yang diajarkan untuk menjadi bekal dan juga baik yang sesuai dengan misi sekolah soal akhlak mulia, santun dalam berperilaku. Sejak awal hal seperti ini sudah diinternalisasikan melalui tata tertib sekolah bahwa dengan memilih sekolah ini untuk menuntut ilmu berarti anda memilih untuk menjadi baik sebab setiap agama mengajarkan kebaikan.Nilai-nilai keagamaan umat Katholik bahwa soal ibadah dan iman itu wilayah gereja, tapi kalau di lingkungan sekolah yang ditekankan adalah solidaritas. Semua warga sekolah untuk melakukan keberpihakan kepada orang miskin sehingga peserta didik yang pernah menuntut ilmu disekolah disini bisa memberi pengaruh kepada masyarakat sesuai dengan visi dan misi yang di embang oleh sekolah.

Hal ini sejalan dengan misi pendidikan Katholik harus sejalan dengan arah dan tujuan sekolah yang tertuang dalam kurikulum. Sebagaimana yang di ungkapkan oleh Grace Gerald (Catholic School: Mission, Markets and Morality, London and Yew York,2002), bahwa pernyataan misi sekolah Katholik dapat diringkas menjadi lima prinsip regulatif, yakni: pendidikan dalam iman (sebagai bagian dari misi keselamatan gereja); keberpihakan kepada orang miskin; formasi dalam solidaritas dan komunitas (untuk hidup dalam komunitas dengan orang lain); pendidikan demi kebaikan bersama (mendorong usaha-usaha bersama demi kebaikan manusia dan kebaikan umum); pendidikan akademik demi pelayanan (pengetahuan dan keterampilan: sebuah sarana dan bukan suatu tujuan) (Darmin Mbula: 2014: 8).

Eksistensi SMP Frater Kendari di bidang pendidikan telah dibuktikan hingga saat sekarang ini ditandai dengan masih mendapat kepercayaan kepada masyarakat untuk menitipkan putra putrinya menimbah ilmu di sekolah ini. Animo masyarakat (orang tua siswa) untuk memasukkan anaknya di SMP Frater Kendari utamanya orang tua yang beragama lain cukup tinggi, hal ini dibuktikan oleh tingkat perbandingan siswa berdasarkan agama di sekolah ini cukup heterogen. Sebagai bahan perbandingan bahwa siswa yang bersekolah di SMP Frater Kendari ini berasal dari semua agama.

Disamping itu, yang menyebabkan tingkat heterogenitas siswa di sekolah ini karena didominasi oleh orang tua siswa tersebut adalah alumni dan sudah merasakan kompetensi pendidik, kedispilinan dan mutu lulusan yang di hasilkan sudah tidak dapat diragukan lagi, sehingga orang tua siswa beranggapan bahwa di SMP Frater Kendari memiliki kualitas yang lebih di banding dengan sekolah swasta lain yang ada di Kota Kendari. Sehingga motivasi orang tua siswa untuk memasukkan anak di SMP Frater bukan di dasarkan pada domain agama melainkan berdasarkan pada aspek kualitas pendidik dan mutu lulusannya.

Kebijakan-kebijakan pembelajaran pendidikan agama dapat dilihat pada komponen pendidikan yang telah disusun yang terdiri dari:

\section{Kurikulum}

Kurikulum yang dikembangkan di SMP Frater Kendari untuk saat ini masih mempergunakan kurikulum KTSP, tapi untuk tahun ajaran 
berikutnya akan menerapkan kurikulum 2013. Kurikulum Tingkat Satuan Pendidikan (KTSP) tersebut disusun dengan mengacu pada Standar Nasional Pendidikan yang terdiri atas standar isi, proses, kompetensi lulusan, tenaga pendidik dan kependidikan, sarana dan prasarana, pengeloaan, pembiayaan, dan penilaian pendidikan.

Pengembangan kurikulum berdasarkan prinsip bahwa peserta didik memiliki posisi sentral untuk mengembangkan kompetensinya agar menjadi manusia yang beriman dan bertaqwa kepada Tuhan Yang Maha Esa, berakhlak mulia, sehat, berilmu, cakap, kreatif, mandiri, dan menjadi warga negara yang demokratis serta bertanggung jawab. Untuk mengejawatahkan segenap potensi yang dimiliki oleh peseta didik tersebut, maka SMP Frater Kendari merumuskan konsep idealnya ke dalam visi yaitu: "Unggul dalam Prestasi, Berakhlak Mulia, dan Pembawa Terang bagi Sesama". Unggul dalam prestasi maksudnya, menguasai Iptek, profesionalitas, manajerial, dan trampil. Berakhlak mulia artinya, beriman, berpengharapan, kasih, budi pekerti yang luhur. Sedangkan pembawa terang dimaknai sebagai pencerdasan bangsa, berkepribadian yang utuh (intelektual, emosional, dan spritual).

Untuk mewujudkan visi tersebut, maka di jabarkan kedalam beberapa misi antara lain: melaksanakan sistem pendidikan nasional yang akuntabel, transparan, dan profesional; menghasilkan peserta didik yang berkualitas tinggi dalam Iptek; menghasilkan pribadi yang beriman, berpengharapan, saling mengasihi, bertanggungjawab, solider, disiplin, dan cinta lingkungan; serta menjadi pelita pembawa terang bagi sesama.

Penyusunan kurikulum KTSP dengan melibat seluruh komponen sekolah seperti kepala sekolah, pendidik dan tenaga kependidikan serta komite sekolah untuk merumus Struktur dan muatan kurikulum yang akan dikembangkan. Di dalam muatan kurikulum terdapat 3 komponen yang dikembangkan diantaranya komponen mata pelajaran yang terdiri dari 10 mata pelajaran yang diantaranya adalah mata pelajaran pendidikan agama yaitu pendidikan agama Katholik, tidak mengakomodir pendidikan agama lain sesuai karakteristik peserta didik yang multi agama.

Komponen muatan lokalyang diselenggarakan Pendidikan Keterampilan Lingkungan Hidup (PKLH), dipilih berdasarkan dengan problem lingkungan dewasa ini yang dari hari kehari semakin memprihatinkan seperti bencana alam, kebakaran hutan, penebangan liar, pencemaran air, problem sampah yang sulit diatasi. Karena itu dengan muatan lokal PKLH ini diupayakan peserta didik sedini mungkin menanamkan kesadaran bagaimana menjaga kelestarian lingkungan walaupun dalam lingkungan yang kecil dilingkup sekolah.Muatan lokal Budi Pekerti dipilih untuk menunjang kurikulum pendidikan agama dan PKn dengan berfokus pada IMTAQ sekaligus mengantisipasi perkembangan dunia yang tak terbendung lagi (globalisasi). Sedangkan muatan Keterampilan, dipilih untuk menambah kreatifitas peserta didik dalam membuat kerajinan tangan dan kuliner.

Komponen pengembangan diri adalah kegiatan yang bertujuan memberikan kesempatan kepada peserta didik untuk mengembangkan dan mengespresikan diri sesuai dengan kebutuhan, bakat, minat sesuai dengan kondisi sekolah. Kegiatan pengembangan diri dibawa bimbingan konselor, pendidik atau tenaga kependidikan yang dapat dilakukan dalam bentuk kegiatan ekstrakurikuler seperti: Dram Band, Kepramukaan, Kelompok Seni Budaya, kelompok tim olah raga, Kelompok Ilmiah Remaja (KIR), dan teater/sanggar.

\section{Pendekatan dan Metode Pembelajaran}

Metode pembelajaran adalah suatu cara yang sistematis digunakan untuk menyampaikan suatu ide, gagasan, pemikiran, wawasan, informasi, atau pengetahuan kepada pesertadidik agar dapat mencapai tujuan yang telah ditentukan (Abudin Nata, dalam Sadikin: 2009: 176).

Metode pembelajaran yang diterapkan oleh guru Pendidikan Agama di SMP Frater Kendari menggunakan dua pendekatan yaitu pendekatan yang terpusat pada guru (teacher centered), yaitu suatu model pembelajaran yang menekankan pada aktivitas pendidik, dan peserta didik bersifat pasif, dan pendekatan yang berpusat pada siswa (students centered), merupakan model pembelajaran yang menekankan pada aktivitas siswa, sementara guru lebih banyak berperan sebagai fasilitator, yang selanjutnya siswa secara aktif mencari dan menemukan sendiri apa yang sedang dipelajari. Sebetulnya pemilihan atau penggunaan pola pendekatan ini bergantung pada metode mengajar yang dipilih oleh guru, jika metode ceramah yang dipilih oleh pendidik tersebut maka gurulah yang dominan dalam proses pembelajaran sehingga model pendekatannya tentu memakai pendekatan yang berpusat pada guru, begitupula 
jika guru memakai metode yang lain seperti, metode diskusi, kerja kelompok, tanya jawab, penugasan, praktek lapangan, demonstrasi dan lain-lain tentunya akan memakai model pendekatan yang berpusat pada siswa. Lebih lanjut diungkapkan bahwa disetiap materi pelajaran terkadang memakai beberapa metode dengan mempertimbangkan karakteristik peserta didik demi tercapainya sistem pembelajaran pendidikan agama Katholik yang efektif dan dapat diterima dan dipahami oleh peserta didik yang beragama lain.

Penggunaan metode pembelajaran pendidikan agama Katholik dapat dilihat pada Rencana Pelaksanaan Pembelajaran (RPP) guru agama yang secara garis besarnya memakai beberapa metode seperti: Metode Ceramah, Diskusi Kelompok, Tanya Jawab, Praktek Lapangan, Demonstrasi, Kerja Kelompok, sharing pendapat, dan lain-lain. Adapun pendekatan yang sering dipakai dengan dialog partisipatif, pemahaman, dan pendalaman iman.

Metode seperti ini dirasa efektif dalam merangsang dan mengairahkan siswa untuk berkreativitas, sehingga kemungkinan potensi yang dimiliki oleh peserta didik dapat tersalurkan dan terpantau oleh pendidik. Oleh karena itu, metode yang dipakai dalam kegiatan pembelajaran tidak tergantung pada satu metode, tetapi disesuaikan dengan kondisi kelas dan lingkungan.

\section{Tenaga Pendidik}

Guru pada hakekatnya tenaga kependidikan yang memikul berat tanggung jawab kemanusiaan, khususnya berkaitan dengan proses pendidikan. Betapa berat beban dan tanggung jawab yang di emban oleh pendidik tersebut sehingga menuntut profesionalitas tinggi dalam proses pembelajaran. Melalui kompetensi profesionalnya pendidik harus mampu mewujudkan langkah-langkah pembelajaran yang inovatif, frogresif, dan kreatif sehingga proses belajar mengajar dapat bermakna serta transfer knowledge dan transfer of value dapat dengan mudah tersampaikan (Trianto, 2010: v).

Pendidik merupakan komponen penting dalam kegiatan belajar mengajar. Pendidik adalah orang yang diberi kepercayaan untuk menciptakansuasana kelas yang kondusif untuk pembelajaran. Pendidik adalah manusia biasa yang mempunyai banyak keterbatasan. oleh karena itu untuk menutupi kelemahan guru perlu dilakukan pembinaan dan penataran dalam rangka melaksanakan pembelajaran.
Secara keseluruhan keberadaan tenaga pendidik yang dimiliki SMP Frater Kendari sebanyak 23 orang, yang terdiri dari PNS 7 orang, Guru Tetap Yayasan (GTY) 9 orang, dan Guru Tidak Tetap (GTT) 7 orang. Sedangkan tenaga kependidikan sebanyak 5 orang yang terdiri dari pegawai tetap 3 orang dan pegawai tidak tetap 2 orang. Jumlah pendidik dan tenaga kependidikan yang beragama Islam sebanyak 2 orang, Kristen 3 orang, Hindu 1 orang dan selebihnya beragama Katholik.

Karakteristik tenaga pendidik yang dimiliki SMP Frater Kendari berdasarkan agama yang dianut tampak beragama. Dari 23 tenaga pendidik terdapat 16 orang yang beragama Katholik, 4 orang beragama Kristen, 2 orang beragama Islam, dan 1 orang yang beragama Hindu.

Ketersediaan tenaga pendidik yang mengampuh mata pelajaran pendidikan agama (Katholik) sebanyak 2 orang, yang rata-rata telah mengajar selama kurang lebih 2 tahun, dan memiliki latar belakang pendidikan sekolah kepastoral. Fr. Vincensius Kehi HHK adalah lulusan dari sekolah Kepastoral Makassar dan Maria Magdalena, adalah lulusan dari Institut Pastoral Indonesia Malang (IPI Malang), jurusan Kateketik.

Pengangkatan tenaga pendidik tersebut di angkat oleh yayasan dengan status guru tetap yayasan dan memiliki kompetensi sesuai dengan latarbelakang pendidikan yang pernah ditempuh. Proses rekrutmen melalui mekanisme yang telah ditentukan oleh yayasan melalui rekomendasi dari pihak sekolah dengan melihat dari sejumlah prasyarat yang harus dimiliki terkait dengan kompetensi akademik. Pihak yayasan melakukan uji kompetensi (fit and proper test) melalui wawancara kemudian dimagangkan, setelah melewati masa magang barulah diangkat menjadi guru tetap yayasan.

\section{Peserta Didik}

Kondisi peserta didik di SMP Frater untuk lima tahun terakhir mengalami perkembangan dari tahun ke tahun. Peserta didik yang tercatat untuk tahun ajaran 2013-2014 sebanyak 301 peserta didik, dengan jumlah rombel sebanyak 9 yang terdiri dari 3 rombel untuk setiap tingkatan/kelas.

Identifikasi peserta didik berdasarkan agama didominasi oleh peserta didik yang beragama Katholik yaitu sebanyak 150 peserta didik, yang tersebar pada 3 tingkatan kelas. (kelas VII $=46$, kelas VIII $=58$, kelas IX $=46$ ). Peserta didik yang 
beragama Kristen sebanyak 119 dengan rincian $($ kelas VII $=52$, kelas VIII $=36$, kelas IX $=31$ ), peserta didik yang beragama Buddha sebanyak 17 orang, terdiri dari $($ kelas $\mathrm{VII}=4$, kelas VIII $=$ 7 , kelas IX $=6$ ), dan peserta didik yang beragama Islam sebanyak 15 , yang meliputi (kelas VII $=6$, kelas VIII $=4$, kelas IX $=5$ ).

Walaupun sekolah ini adalah sekolah binaan yayasan keagamaan Katholik yang memiliki ciri khas pembelajaran agama Katholik, melalui kebijakan pimpinan yang telah membuka diri menerima peserta didik dari pemeluk agama yang berbeda, namun dalam penyusunan kurikulum tidak mengakomodir kepentingan peserta didik yang berbeda agama. Kondisi peserta didik yang multi agama ini tidak di fasilitasi dengan ketersediaan guru-guru agama yang mengharuskan peserta didik tersebut menerima pelajaran agama sesuai dengan agama yang dianutnya, sebagaimana yang diamanatkan dalam Peraturan Pemerintah No. 55 Tahun 2007 tentang Pendidikan Agama dan Keagamaan pada pasal 4 ayat 2 yang berbunyi: "Setiap peserta didik pada satuan pendidikan di semua jalur, jenjang, dan jenis pendidikan berhak mendapat pendidikan agama sesuai agama yang dianutnya dan diajar oleh pendidik yang seagama".

\section{Sumber Belajar/Media Pembelajaran}

Sarana dan prasarana yang merupakan salah satu unsur pendukung peroses pembelajaran sehingga tujuan pendidikan dapat tercapai secara optimal. Sarana dan prasarana yang dimaksud seperti; ruangan belajar sebanyak 9 rombel, ruangan kepala sekolah 1 buah, ruangan tata usaha 1 buah, ruangan guru 1 buah, ruangan BK 1 buah, ruang perpustakaan 2 buah, ruang OSIS, UKS, Laboratorium IPA, Komputer, ruang multimedia, ruang teater, ruang alat musik, aula, dan ruang koperasi masing-masing 1 buah. Disamping itu terdapat pula koperasi, kantin, serta lapangan upacara dan olah raga.

Sedangkan untuk memperlancar proses pembelajaran pendidikan agama telah didukung oleh ketersediaan sumber belajar sebagai sarana media pembelajaran baik dalam bentuk cetak seperti; kitab suci yaitu kitab suci agama Katholik; buku pelajaran siswa, dan buku pegangan guru; Lembaran Kegiatan siswa (LKS) berupa lembaranlembaran berisi tugas yang harus dikerjakan peserta didik. Lembaran kegiatan biasanya berupa petunjuk dan langkah-langkah untuk mengerjakannya; foto atau gambar tokoh-tokoh yang sangat peduli terhadap sesama yang dapat menginspirasi peserta didik dan atau yang dapat di jadikan teladan seperti; Ibu Theresia dari Calcuta, Romo Mangunwijaya dari Jogjakarta, Gusdur sebagai teladan tokoh pemersatu dan bapak kerukunan, serta Jokowi, dan tokoh-tokoh yang lainnya; koran/majalah, merupakan bahan informasi atau berita tertulis mengenai suatu masalah yang berhubungan dengan topik yang dibahas; alat peraga pembelajaran dengan memanfaat kertas atau karton dalam bentuk segi empat kemudian ditempel di papan tulis saat kegiatan pembelajaran berlangsung.

Disamping itu terdapat pula media atau sumber belajar yang biasa di pakai yang bukan dalam bentuk cetak seperti; laptop dan Proyektor, media ini sering dipergunakan oleh pendidik dalam menyampaikan materi dalam bentuk slide power point; kaset atau CD (Compact Disk), Media kaset/ CD dapat menyimpan suara yang dapat secara berulang-ulang dapat diperdengarkan kepada peserta didik dalam penggunaannya memerlukan bantuan alat dan bahan lainnya seperti tape recorder, Laptop dan LCD; kisah atau Cerita, penuturan guru tentang pengalaman-pengalaman yang telah di lalui oleh seseorang; pemutaran film pendek, merupakan alat bantu yang didesain sebagai bahan ajar. Umumnya program video telah dibuat dalam rancangan lengkap, sehingga setiap akhir penanyangan film peserta didik dapat menguasai satu atau lebih kompetensi dasar; pengeras suara yang di pasang disetiap sudut kelas yang dipergunakan untuk kegiatan berdoa.

\section{Sistem Evaluasi}

Pelaksanaan pembelajaran pendidikan agama di SMP Frater Kendari tidak terlepas dari keberadaan guru agama yang dimilikinya, karena SMP Frater Kendari adalah sekolah dibawah yayasan keagamaan Katholik, sehingga pendidikan agama yang dipelajari adalah pendidikan agama Katholik dengan jumlah guru agama Katholik sebanyak dua orang yaitu bapak Fr. Vincensius Kehi HHK, dan ibu Maria Magdalena, keduanya merupakan lulusan sekolah agama Katholik yang mengajar pada 9 rombongan belajar. Untuk kelas VII materi pendidikan agama Katholik di ajarkan oleh bapak Fr. Vincensius Kehi HHK, sedangkan pada kelas VIII dan IX di pegang oleh ibu Maria Magdalena.

Evaluasi pembelajaran merupakan penilaian kegiatan dan kemajuan belajar peserta didik yang dilakukan secara berkala berbentuk ujian, 
praktikum, tugas, dan atau pengamatan guru. Bentuk evaluasi yang diberikan meliputi ujian tengah semester, ujian akhir semester, dan ujian tugas akhir

Menurut Trianto (2010: 254), bahwa tujuan dari penilaian adalah untuk mengukur seberapa jauh tingkat keberhasilan proses belajar mengajar yang telah dilaksanakan oleh guru. Disamping itu penilaian juga bertujuan untuk mengetahui seberapa jauh keberhasilan guru dalam melaksanakan proses pembelajaran, yang digunakan sebagai feedback/ umpan balik bagi guru dalam merencanakan proses pembelajaran selanjutnya.

Pelaksanaan evaluasi yang digunakan oleh guru agama Katholik di dilakukan setelah peserta didik selesai proses pembelajaran pada satu pokok bahasan, Evaluasi yang diberikan oleh guru umumnya untuk mengetahui apakah tujuan pembelajaran tersebut telah tercapai atau belum, dan untuk mengetahui apakah pengetahuan sikap dan keterampilan telah benar-benar dimiliki oleh siswa atau belum. Bentuk dan Jenis evaluasi yang diberikan secara tertulis dan tidak tertulis (lisan) yang dilaksanakan pada tengah dan akhir semester.

Selain itu evaluasi diberikan dalam bentuk tugas-tugas kegiatan intra kurikuler yang dilakukan oleh siswa terdiri dari kegiatan: tugas berstruktur (pekerjaan sekolah/pekerjaan rumah) pelaksanaan praktek PAK seperti (kunjungan, pelayanan gerejawi melalui kesaksian pujian, dan lain-lain), praktek ibadah (awal dan akhir pelajaran, kebaktian dan lain-lain), serta evaluasi tengah dan akhir semester.

Sedangkan siswa yang dianggap belum mampu memenuhi standar kompetensi yang diharapkan akan diadakan remedial atau pengayaan oleh guru yang bersangkutan, dan pelaksanaan remedial atau pengayaan dilakukan sebelum semester.

Semua bentuk evaluasi yang di terapkan oleh para pendidik mata pelajaran pendidikan agama Katholik berlaku sama kepada seluruh siswa tanpa melihat latar belakang agama yang di anutnya.

\section{Tipe Inovasi yang dilakukan oleh Guru Agama}

SMP Frater Kendari yang merupakan sekolah swasta yang dikelola oleh Yayasan Taman Tunas dengan ciri khas pembelajaran pendidikan agama Katholik, namun karakteristik pendidk dan peserta didiknya sangat heterogen jika dilihat dari agama yang dianutnya. Oleh karena itu, bagi pendidik yang memberikan pembelajaran agama Katholik dituntut untuk melakukan inovasi pembelajaran terhadap peserta didik yang multi agama tersebut agar penyampaian materi dapat tersampaikan dengan baik. Materi-materi yang dibahas bersifat umum (universal) sesuai dengan kehidupan mereka setiap hari. pada kelas VII hampir semua materi ajar bersifat universal seperti "Hidup bersama orang lain, aku dan sesama di cintai Allah, Yesus berbelas kasih, Yesus mengampuni, Yesus Rela Berkorban, Yesus peduli terhadap penderitaan sesama, Yesus Kristus sang pendoa, Yesus mewartakan cinta tanpa pengkotakan, dan Yesus memperjuangkan kesetaraan martabat manusia".

Hasil wawancara yang dilakukan oleh bapak Fr. Vincensius Kehi HHK, mengatakan bahwa inovasi yang dilakukan sedapat mungkin peserta didik yang beragama selain agama Katholik mampu memahami materi yang disampaikan, olehnya itu apa yang telah digariskan dalam silabus dan RPP dilakukan inovasi pembelajaran, kalau hanya mengikuti alur dari RPP seolah-olah tidak ada sesuatu yang bisa berikan. Menurut beliau pada prinsipnya yang penting mereka senang dan bisa memahami apa yang disampaikan, dan yang pasti bahwa tetap berpedoman pada rambu-rambu yang ada. seperti pada materi tentang "Yesus peduli terhadap sesama", penjelasan yang disampaikan dapatdipahami secara umum tentangbagaimana mereka dalam kehidupan sehari-hari membina rasa peduli terhadap sesama dalam tindakantindakan konkrit dalam hidup bersama baik dengan keluarga dirumah, di sekolah dengan teman-teman, guru, warga dimasyarakat, dan siapa saja yang mereka jumpai.(Wawancara, Rabu, 26/3/2014).Itulah strategi dan inovasi yang biasa diterapkan oleh bapak Fr. Vincensius Heki HHK ketika mengajarkan pendidikan agama Katholik. Untuk membangkitkan siswa dalam menerima pelajaran biasanya melakukan umpan balik dengan mengajukan pertanyaan kepada peserta didik terkait materi yang di sampaikan seperti bagaimana memahami sikap peduli dalam kehidupan seharihari berdasarkan keyakinan agama yang dianut.

Perlu dipahami bahwa pembelajaran Pendidikan Agama Katholik (PAK) adalah mata pelajaran yang berhubungan langsung dengan dimensi keagamaan dengan menekankan pada perubahan perilaku spritual peserta didik, sehingga muatan ranah afektif dan psikomotorik lebih ditekankan daripada ranah kognitifnya, sehingga melalui pembelajaran PAK diharapkan siswa dapat mengalami perjumpaan dengan Allah di dalam Tuhan Yesus Kristus, Sang Sumber Nilai yang 
membawa perubahan pada diri siswa, khususnya perkembangan iman serta mental moralnya selain perkembangan pengetahuan dan psikomotoriknya.

Selain itu, untuk menumbuhkan semangat keimanan peserta didik, pihak sekolah selalu melakukan kegiatan-kegiatan yang bernuansa keagamaan sebagai wahana bagi peserta didik untuk menemukan hakekat dirinya melalui pendalaman iman. Kegiatan keagamaan yang dilakukan oleh SMP Frater Kendari ada yang berlaku untuk semua siswa dan ada pula kegiatan keagamaan yang hanya diikuti oleh siswa yang beragama Katholik saja.

Ada beberapa kegiatan keagamaan yang memang sudah di programkan oleh sekolah dengan melibatkan para guru dan pengurus OSIS adalah sebagaui berikut: kegiatan rekoleksi dengan mengajak siswa untuk keluar dari lingkungan sekolah sebagai ajang sosialisasi di luar untuk melakukan perenungan sebagai sarana pendalaman iman peserta didik. Rekoleksi adalah mengulang atau memilah-milah kembali perjalanan hidup di waktu-waktu telah lalu entah itu hal baik maupun yang tidak baik kemudian sekaligus berusaha untuk meninggalkan yang tidak baik dan meningkatkan yang baik. Kegiatan ini di ikuti oleh seluruh peserta didik; perayaan ekaresti yang di laksanakan sebulan sekali pada minggu pertama tepat pada hari jum'at dengan mendatang pastor sebagai pembicara dan semua siswa ikut dalam kegiatan ini, biasanya dilaksanakan di lingkungan sekolah; pendalaman iman setahun dua kali yaitu pada saat mendekati hari Paskah diisi dengan pendalaman iman, dan masa sebelum natal.

Materi pendalaman iman ini sudah disiapkan dari Keuskupan Agung dalam bentuk teks kita tinggal menyampaikan, kegiatan ini hanya di ikuti oleh peserta didik yang beragama Katholik; doa Rosario, dilaksanakan setiap bulan Mei dan bulan Oktober kita melakukan deposi kepada bunda Maria yaitu berdoa khusus dan melakukan penghormatan kepada bunda Maria, kegiatan ini hanya di ikuti oleh siswa yang beragama Katholik. Doa Rosario di lakukan di sebuah gua dan patung Maria yang sengaja di buat di sekitar lingkungan sekolah. doa Anjelius, yaitu doa malaikat tuhan dilaksanakan setiap hari tepat pada pukul 12.00 siang, pelaksanaan doa di koordinir oleh OSIS. Natal bersama, yang dihadiri oleh seluruh komponen sekolah, komite sekolah dan orang tua siswa. Perayaan Hari Paskah. Aksi Puasa Pembanguanan (APP), dan itu berjalan kurang lebih sebulan selama 7 minggu dari masa pra Paskah, dan selama pra paskah itu diisi dengan selain berpuasa dan pantang juga lebih banyak membaca firman tuhan, lebih banyak berdoa menjalin hubungan baik dengan tuhan kemudian dari kekurangan yang kita miliki kita membuka hati dan membuka diri untuk membantu sesama yang berkekurangan dan dalam memberi sedekah. Jadi program ini dijalankan oleh pengurus OSIS setiap hari selama masa pra paskah dengan mengedarkan kotak sumbangan ke setiap kelas. Sumbangan yang diberikan dalam bentuk sukarela disisihkan dari uang jajan mereka dan tidak ada unsur paksaan. Kegiatan ini dilaksanakan dalam setahun dua kali yaitu sebelum paskah dan sebelum natal. Tema lima tahun yaitu "Mewujudkan Hidup Sejahtera", dan tema khusus untuk tahun 2014 ini yaitu "Belajar Sepanjang Hidup".

Walaupun SMP Frater Kendari sekolah swasta yang di kelola oleh Yayasan Taman Tunas di mana kurikulum pendidikan agama Katholik sudah di atur sedemikian rupa dari yayasan, akan tetapi dengan kreativitas dan kebijakan sekolah yang melihat penting untuk menambahkan halhal yang sesuai dengan kondisi siswa yang multi agama, sehingga materi pelajaran agama Katholik yang diberikan paling tidak dapat menyentuh atau mengandung nilai-nilai yang umum (universal), yang sedapat mungkin dapat dipahami oleh siswa yang beragama non Katholik, misalnya tentang solidaritas, nilai-nilai cinta, persaudaraan, gotong royong. Memang kadangkala ada referensi dari kitab suci tetapi kandungannya juga terdapat di kitab suci Alquran dan kitab suci lain, sehingga ada kesesuaian. Contoh konkrit pada saat mendekati Hari Paskah semua siswa dapat menyisihkan sebagian dari uang jajannya untuk berderma dalam kegiatan "Aksi Puasa Pembangunan (APP)". Kegiatan ini bertujuan untuk menumbuhkan jiwa kepekaan, empati, dan solidaritas siswa untuk ikut membantu orang-orang yang berkekurangan lewat sumbangan secara sukarela setiap hari selama masa menjelang peringatan hari Paskah yang dikoordinir oleh pengurus OSIS bidang kerohanian.

Karakteristik peserta didik yang multi agama menuntut guru pendidikan agama Katholik dalam memberikan materi harus memiliki daya kreatifitas dan inovasi. Sejauh ini berdasarkan wawancara kepada para guru agama Katholik telah melakukan berbagai upaya inovasi dan kreatifitas dalam pembelajaran pendidikan agama Katholik, menurut pendapat bapak Fr. Vincensius Heki HHK, mengatakan: "Soal kreativitas sejauh ini saya biasa memberikan penekanan dalam pembelajaran 
seperti tema pergaulan itu saya memberikan contoh yang sunguh-sungguh riel supaya mereka bisa memahami bahwa pergaulan biasa seperti apa dan pergaulan khusus bagaimana".(Wawancara, Selasa, 25/3/2014.

Pengamatan peneliti, ketika mengikuti beberapa kali kegiatan pembelajaran di kelas VII cukup memahami apa yang di ungkapkan oleh para guru agama tersebut bahwa ketika memberikan materi tidak lupa memberikan perbandingan bahwa apa yang selama ini di lakukan oleh umat Katholik juga dapat dilakukan umat lain. Seperti pembahasan dengan pokok bahasan "Yesus sangat peduli terhadap penderitaan sesama", dengan melihat fenomena sekarang yang begitu banyak pemimpin yang salah dalam memanfaatkan jabatannya, kehidupan zaman modern semakin menumbuhkan sifat egoisme, semakin banyak orang yang tidak peduli lagi terhadap sesama,bahkan mereka hanya melakukan sesuatu hanya untuk menguntungkan diri sendiri. Sehingga Yesus dan pemimpin umat lainnya sangat menentang pemimpin yang seperti itu.

Materi pendidikan agama Katholik penekanannya pembinaaan iman peserta didik, sehingga untuk menumbuhkan semangat keimanan peserta didik tersebutpihak sekolah setiap tahun mengadakan kegiatan di luar sekolah dalam bentuk rekoleksi. Kegiatan rekoleksi ini tiap tahun mengusung tema sentral dan untuk tahun lalu memilih tema tentang "pergaulan bebas", tempat yang dipilih biasanya ditempat-tempat yang mendukung kegiatan tersebut untuk bisa melakukan perenungan. Tujuan atau sasaran yang ingin dicapai dari kegiatan rekoleksi tersebut semata-mata untuk pembinaan imam peserta didik. Kegiatan ini di ikuti oleh seluruh peserta didik.

Pola pembinaan keimanan bagi siswa-siswa non Katholik dikembalikan kepada keluarga (orang tua) untuk melakukan pembinaan. Intinya bahwa di sekolah tetap belajar agama Katholik. Proses pembinaan sikap dan perilaku siswa terjadi di lingkungan keluarga, sekolah dan masyarakat tentunya jika pembinaan dilakukan di lingkungan sekolah berarti yang berperan melakukan kontrol adalah sekolah dibawah kendali para guru. Begitupun ketika berada dilingkungan keluarga dan masyarakat maka orang tua lah yang melakukan kontrol dan pembinaan.

Bagi siswa yang beragama Islam diberikan toleransi setiap hari Jumat sehingga semua siswa dipulangkan lebih awal dari biasanya dengan harapan agar siswa yang beragama Islam dapat menjalankan Salat Jumat bersama dengan keluarganya. Akan tetapi untuk mengetahui apakah siswa yang beragama Islam itu menjalankan kegiatan ibadah Salat Jum'at tidak ada jaminan, karena tolak ukurnya tidak jelas dan tidak ada format yang diberikan oleh guru kepada siswa sebagai bukti seperti ceklis tanda tangan dari pengurus masjid atau khatib yang membawakan Kutbah Jum'at.

Khusus untuk peserta didik yang beragama Islam, ketika bulan puasa tiba guru agama yang diberikan tugas mengingatkan pada peserta didik yang beragama lain untuk memahami dan menghormati bahwa saat ini teman-teman yang muslim telah menjalankan ibadah puasa jadi harus toleran dan saling menghormati dalam bentuk tidak makan dan minum di dalam sekolah secara terbuka, tetapi makan dan minum di tempat yang kira-kira aman bagi peserta didik yang sementara menjalankan ibadah puasa. Ini adalah kebijakan yang di ambil oleh sekolah walaupun tidak dalam bentuk tertulis tapi sudah menjadi bagian tradisi setiap bulan ramadhan.

Proses pembelajaran pendidikan agama Katholik diawal dengan doa bersama di halaman sekolah sebelum pelajaran dimulai yang dipimpin oleh salah seorang siswa yang ditunjuk secara bergilir oleh pengurus OSIS. Di dalam kelas, kegiatan pendahuluan di lakukan selama 10 menit diawal dengan salam dilanjutkan doa, terkadang guru agama minta kepada siswa secara spontan dengan menunjuk langsung untuk membacakan doa dan itu bukan hanya siswa yang beragama Katholik pokoknya siapa yang bisa dari agama apapun kemudian absensi siswa, setelah absen ada motivasi untuk memberi gambaran sedikit tentang pelajaran yang sudah di terima minggu lalu kemudian menghubungkan dengan pelajaran yang dibahas (apersepsi) setelah itu baru masuk proses pembelajaran.

\section{Faktor Pendukung dan Penghambat Pelaksanaan Inovasi Pembelajaran Pendidikan Agama Di SMP Frater Kendari}

SMP Frater Kendari terus memacu diri untuk meraih prestasi baik akademik maupun non akademik, namun upaya yang terus dilakukan tentu saja tidak terlepas dari adanya potensi kekuatan dan peluang, begitu juga hambatan dan kelemahan yang selalu merintangi. Oleh karena itu, untuk melihat sejauh mana potensi-potensi tersebut memberikan pengaruh terhadap perkembangan pendidikan 
utamanya pelaksanaan inovasi pembelajaran pendidikan agama, maka dapat di analisis melalui analisis SWOT, yang terdiri dari faktor kekuatan (strenght), kelemahan (weakness), peluang (oportunities), dan ancaman (trength). Lebih jelasnya ke 4 faktor yang menjadi pertimbangan dalam melakukan analisis ini adalah sebagai berikut:

\section{Faktor Pendukung \\ Kekuatan}

SMP Frater Kendari sebagai salah satu unit pelaksanaan pendidikan memiliki beberapa faktor pendukung yang menjadi kekuatan dalam penyelenggaraan proses pendidikan. Jumlah Tenaga pendidik sebanyak 23 orang ini mengajar sesuai dengan kompetensi akademiknya, 19 orang $(73,91 \%)$ diantaranya telah yang berlatar belakang Strata Satu (S1), 2 orang $(8,69)$ tenaga pendidik telah menyelesaikan studinya pada jenjang Magister (S2), dan 2 orang berlatar belakang Diplomaa (D3) (4,54\%). Sebagian besar pernah mengikuti penataran dan diklat kependidikan yang sesuai dengan spesifikasi mata pelajaran masing-masing, baik pada tingkat kab/kota, provinsi maupun tingkat nasional.

Ketersediaan guru agama sebanyak 2 orang, yang rata-rata telah mengajar selama kurang lebih 2 tahun, dan memiliki latar belakang pendidikan sekolah kepastoran. Fr. Vincensius Kehi HHK adalah lulusan dari sekolah kepastoral Makassar dan Maria Magdalena, adalah lulusan dari Sekolah Tinggi Ilmu Pastoral Indonesia Malang (STIPI Malang), dengan jurusan Kateketik.

Berkaitan dengan penyelenggaraan administrasi sekolah, tenaga administrasi yan dimiliki terdiri dari 1 orang Kepala Tata Usaha dengan latar belakang pendidikan SMA, 1 orang sekertaris tamatan S1, sedangkan tenaga perpustakan berjumlah 1 orang lulusan SMK, 1 orang satpam tamatan SMA, dan juga memiliki 1 orang bujang sekolah tamatan SMA.

Sarana dan prasarana yang merupakan salah satu unsur pendukung peroses pembelajaran sehingga tujuan pendidikan dapat tercapai secara optimal. Sarana dan prasarana yang dimaksud seperti; ruangan belajar sebanyak 9 rombel, ruangan kepala sekolah 1 buah, ruangan tata usaha 1 buah, ruangan guru 1 buah, ruangan BK 1 buah, ruang perpustakaan 2 buah, ruang OSIS, UKS, Laboratorium IPA, Komputer, ruang multimedia, ruang teater, ruang alat musik, aula, dan ruang koperasi masing-masing 1 buah. Disamping itu terdapat pula koperasi, kantin, serta lapangan upacara dan olah raga.

Sedangkan untuk memperlancar proses pembelajaran pendidikan agama telah didukung oleh fasilitas sarana media pembelajaran seperti buku-buku paket untuk guru dan siswa, LKS, kitab suci, laptop, Proyektor, dan pengeras suara yang di pasang disetiap sudut kelas yang dipergunaka untuk kegiatan berdoa.

\section{Peluang}

Dalam menjalankan fungsinya, SMP Frater Kendari dengan segala keterbatasan juga memiliki peluang untuk berkembang menjadi sebuah unit pelaksanaan pendidikan yang besar. Hal ini dapat didukung oleh peluang utamanya kondisi sosial dan keamanan yang cukup kondusif, khususnya di Kota Kendari dan Provinsi Sulawesi Tenggara pada umumnya. Disamping itu adanya dukungan dari orang tua siswa yang sangat tinggi dan peluang kerja sama dengan beberapa instansi terkait maupun lingkungan dunia usaha yang cukup mempunyai kepedulian dengan kemajuan pendidikan.

Peluang lain yang dapat meningkatkan citra pendidikan selain memiliki alumni yang dapat diterima diberbagai sekolah lanjutan baik di SMA Negeri maupun dibeberapa sekolah swasta favorit di luar kota kendari seperti di Kota Makassar dan di pulau Jawa, sehingga animo masyarakat dan orang tua siswa untuk memasukkan anaknya untuk bersekolah di SMP Frater Kendari utamanya siswa yang non agama Katholik cukup tinggi.

Suasana lingkungan sekolah sangat kondusif karena selalu di kontrol oleh kepala sekolah, guru piket dan pengurus OSIS mulai dari kerapian berpakaian, keterlambatan, penggunaan telepon seluler (semau siswa dilarang membawa HP). Karakteristik siswanya juga multi agama, begitupun dengan tenaga pendidikan berasal dari berbagai agama.

\section{Faktor Penghambat \\ Kelemahan}

Disamping faktor pendukung yang menjadi kekuatan maupun peluang terhadap pelaksanaan pendidikan di SMP Frater Kendari, juga memiliki faktor penghambat yang dianggap menjadi titik kelemahan dan tantangan pelaksanaan proses pendidik yang harus dibenahi. Kelemahan itu datangnya baik dari segi sumber daya manusia maupun sarana dan prasarana pendukung.

Dari segi sumber daya manusia, khususnya tenaga pendidik bahwa masih ada sebagian 
pendidik masih kurang memiliki motivasi dalam melaksanakan tugas mengajar yang menjadi beban kerjanya. Hal ini menyebabkan unjuk kerja atau kinerja pendidik tersebut menurun yang berdampak pada prestasi belajar siswa yang rendah.

Pencapaian prestasi akademik siswa yang kurang, juga disebabkan tingkat akademik dan latar belakang ekonomi siswa, banyak yang berkategori rendah. Serta kurang memadainya alat bantu dan media pembelajaran pada semua mata pelajaran. Juga belum memiliki laboratorium bahasa yang menjadi sarana utama pembelajaran rumpun bahasa (bahasa Indonesia dan Inggris).

\section{Tantangan}

Berkaitan dengan pelaksanaan proses pendidikan, SMP Frater Kendari menghadapi beberapa kendala yang menjadi penghambat efektivitas penyelenggaraan pendidikan. Sekolah masih tahap renovasi seperti proses pembangunan pintu gerbang sekolah dan sebagian bangunan sekolah masih dalam tahap pengecetan.

Sosialisasi harus lebih gencar dilakukan oleh pimpinan dan seluruh komponen pendidikan seperti pendidik dan tenaga kependidikan untuk mempromosikan eksistensi dan kelebihankelebihan yang di miliki oleh SMP Frater Kendari agar dapat menarik minat peserta didik.

Lulusan yang diterima masuk pada jenjang sekolah menengah atas (SMA favorit) cukup menghadapi kompetisi yang ketat dan sangat selektif.

Khusus pada pembelajaran pendidikan agama, hanya mengajarkan pendidikan agama Katholik, sedangkan karakteristik peserta didiknya multi agama, sehingga di tuntut untuk menyediakan guru agama bagi siswa yang seagama. Walaupun dulunya pernah kurang lebih 5 tahun telah menyediakan guru yang seagama dengan siswa, dan dua tahun terakhir ini penyediaan guru agama yang seagama dengan peserta didik tidak tersedia lagi karena adanya kebijakan dari yayasan.

\section{PENUTUP}

SMP Frater Kendari salah satu sekolah swasta binaan yayasan keagamaan Katholik pengekelolannya dikendalikan oleh Yayasan Taman Tunas yang berpusat di Makassar, yang didirikan pada tahun 1970.Pendidikan agama yang di ajarkan adalah Pendidikan agama Katholik kepada semua peserta didik dengan sesuai ciri khas sekolah Katholik, tanpa melihat Karakteristik peserta didik yang multi agama. Materi pelajaran agama Katholik yang diberikan paling tidak dapat menyentuh atau mengandung nilai-nilai yang umum (universal), yang sedapat mungkin dapat dipahami oleh siswa yang beragama non Katholik, misalnya tentang solidaritas, nilai-nilai cinta, persaudaraan, gotong royong. Pembelajaran Pendidikan Agama Katholik (PAK) berhubungan langsung dengan dimensi keagamaan dengan menekankan pada perubahan perilaku spritual peserta didik, sehingga muatan ranah afektif dan psikomotorik lebih ditekankan daripada ranah kognitifnya.

Implementasi pembelajaran pendidikan agama karena adanya dukungan pendidik agama Katholik yang memiliki kompetensi akademik yang merupakan lulusan dari sekolah kepastoran, dan masa mengajarnya memasuki tahun tiga. Ketersediaan sarana dan prasarana pembelajaran cukup tersedia seperti buku-buku paket untuk guru dan siswa, LKS, kitab suci, laptop, proyektor, serta pengeras suara yang di pasang disetiap sudut kelas yang dipergunaka untuk kegiatan berdoa. Suasana lingkungan sekolah sangat kondusif karena selalu di kontrol oleh kepala sekolah, guru piket dan pengurus OSIS mulai dari kerapian berpakaian, keterlambatan, penggunaan telepon seluler (semau siswa dilarang membawa HP). Di samping itu karakteristik siswanya multi agama, begitupun dengan tenaga pendidikan berasal dari berbagai agama.

Sedangkan yang menjadi penghambat datangnya baik dari segi sumber daya manusia maupun sarana dan prasarana pendukung. Dari segi sumber daya manusia, khususnya tenaga pendidik bahwa masih ada sebagian pendidik yang kurang memiliki motivasi dalam melaksanakan tugas mengajar yang menjadi beban kerjanya. Hal ini menyebabkan unjuk kerja atau kinerja pendidik tersebut menurun yang berdampak pada prestasi belajar siswa yang rendah. Pencapaian prestasi akademik siswa yang kurang, juga disebabkan tingkat akademik dan latar belakang ekonomi siswa, banyak yang berkategori rendah. Lulusan yang diterima masuk pada jenjang sekolah menengah atas (SMA favorit) cukup menghadapi kompetisi yang ketat dan sangat selektif. Khusus pada pembelajaran pendidikan agama, hanya mengajarkan pendidikan agama Katholik, sedangkan karakteristik peserta didiknya multi agama, sehingga di tuntut untuk menyediakan guru agama bagi siswa yang seagama. Serta kurang memadainya alat bantu dan media pembelajaran pada semua mata pelajaran. Juga belum memiliki laboratorium bahasa yang menjadi 
sarana utama pembelajaran rumpun bahasa (bahasa Indonesia dan Inggris).

\section{UCAPAN TERIMA KASIH}

Tulisan ini dapat penulis selesaikan berkat bantuan berbagai pihak. Oleh karena itu, penulis ingin menghaturkan rasa terima kasih kepada: Kepala Balai Litbang Agama Makassar H. Hamzah Harun Al-Rasyid yang telah menugaskan dan memberikan kepercayaan kepada penulis untuk melakukan penelitian tentang Implementasi Pendidikan Agama pada Yayasan Keagamaan di Kota Kendari dengan mengambil lokasi penelitian pada SMP Frater Kota Kendari. Ucapan terima kasih pula penulis haturkan kepada bapak $M$. Sofyan BR selaku peneliti madya yang selalu memberikan bimbingan dan mengoreksi tulisan ini terkait metodologi penulisan. Kepala Sekolah SMP Frater Fr. Kornelius W Banin HHK begitu juga ucapan terima kasih kami haturkan kepada guru agama bapak Fr. Vincensius Kehi HHK, dan ibu Maria Magdalena yang telah meluangkan waktu untuk diwawancarai berkaitan penelitian ini.

\section{DAFTAR PUSTAKA}

Abudin Nata. 2009. Perspektif Islam Tentang Strategi Pembelajaran. Jakarta: Kencana.

Anchok, Djamaluddin. 2012. Psikologi Kepemimpinan dan Inovasi. Jakarta. Erlangga.

Basri, Husain Hasan. 2013. Makalah: Pendidikan agama pada Sekolah Islam.
Bogdan, Robert C. \& Sari Knopp Biklen. 1982. Qualittive research for education; Boston, Allyn and Bacon inc.

Direktorat Jenderal Pendidikan Islam DEPAG RI. 2006. Undang-Undang dan Peraturan Pemerintah RI tentang Pendidikan. Jakarta Kemenag Kota Kendari, 2013. Data Emis: Jumlah Penduduk Kota Kendari berdasarkan Kecamatan.

Kurikulum KTSP SMP Frater Kendari Tahun Pelajaran 2013-2014.

Nata, Abudin. 2009. Perspektif Islam Tentang Strategi Pembelajaran. Jakarta: Kencana.

Neil Postman. 2001. Matinya Pendidikan: Refleksi NilaiNilai Sekolah. Yokyakarta: Jendela.

Pdt. Em. Budhiadi Henoch. 2006. Pendidikan Agama Kristen (PAK) Selayang Pandang.

RP. Mbula Darmin, OFM. 2014. "Kepemimpinan Sekolah Katholik: Kompetensi Kepala Sekolah sebagai Pemimpin Iman" dalam Jurnal Educare Nomor 12/X/2014. Jakarta.

Sadikin, Muhammad Ali. 2013. "Inovasi Guru dalam Penggunaan Metode dan Bahan Ajar Pembelajaran PAI di SD Nasima Semarang". dalam Undergraduate (S1) Thesis, IAIN Walisongo.

Sugiyono. 2005. Metode Penelitian pendidikan Pendekatan Kuantitatif, Kualitatif, dan R\&D. Bandung: Alfabet.

Tamburaka, Rustam. 2003. Sejarah Sultra dan 40 tahun Sultra Membangun Provinsi Sulawesi Tenggara.

Trianto. 2009. Mendesain Model Pembelajaran Inovatif, Progresif. Jakarta. Kencana Prenada Media Group.

Udin Saefudin Sảud. 2008. Inovasi Pendidikan. Bandung: Alfabeta. 